\title{
LITERATURE ON THE VALUE ADDED INTELLECTUAL CAPITAL
}

\author{
DOI: 10.17261/Pressacademia.2020.1366 \\ PAP- V.12-2020(30)-p.101-103
}

\section{Suleyman Sen ${ }^{1}$, Volkan Demir ${ }^{2}$}

${ }^{1}$ Burdur Mehmet Akif Ersoy University, Department of Customs Management, Burdur, Turkey.

suleymansen@mehmetakif.edu.tr, ORCID: 0000-0002-4851-2270

${ }^{2}$ Galatasaray University, Department of Business Administration, İstanbul, Turkey. vdemir@gsu.edu.tr, ORCID: 0000-0001-5313-2320

\section{To cite this document}

Sen, S., Demir, V., (2020). Literature on the value added intellectual capital. PressAcademia Procedia (PAP), V.12, p.101.103.

Permanent link to this document: http://doi.org/10.17261/Pressacademia.2020.1366

Copyright: Published by PressAcademia and limited licensed re-use rights only.

\begin{abstract}
Purpose- The purpose of this study is to classify academically important studies related to the Pulic's (1998; 2004) "value added intellectual capital (VAIC)" which is one of the model that attracts the interest of academics studying intellectual capital; and hence, to especially contribute to the Turkish literature and help future researchers.

Methodology- In our literature review study, studies available with the topic of "VAIC" or "value added intellectual capital" in the Web of Science database over the period of 2015 and 2020 and that which are categorised as "Business", "Economics" and "Business Finance" are analysed.

Findings- This literature review reveals that more than $65 \%$ of the studies were found to be published in 2018 and after, so it has been a subject of great interest in the academic world in recent years. As a result of our literature study, it was concluded that the effect of intellectual capital on financial performance is the most investigated topic. To measure this effect it has seen that; generally the panel data regression method is used. In all 37 studies included in the analysis, VAIC or any subcomponent was found to be statistically significant and positively associated with ROA. However, only 5 studies found that VAIC or any subcomponent was statistically significant and negatively associated with ROA. In these studies addressing accounting and finance literature; while VAIC (Pulic, 1998; 2004) is modifiying; innovation expenditures, advertising expenditures and social welfare expenditures are taken into account.

Conclusion- Based on the analysis findings, it can be concluded that intellectual capital investments have become increasingly important for companies in recent years, regardless of the sector. According to the results obtained, it has been determined that VAIC and its subcomponents increase financial performance in most of the studies, regardless of country or sector. In addition, studies conducted in recent years shows that investments made in innovation capital such as "R\&D expenditures" or in relational capital such as "advertising and marketing expenditures" are also intellectual capital investments and they can provide competitive advantage to companies.
\end{abstract}

Keywords: Intellectual capital, value added intellectual capital, financial performance, innovation capital, relational capita

JEL Codes: O 34, E 22, L 25

\section{ENTELEKTÜEL KATMA DEĞER KATSAYISI ÜZERINE ULUSLARARASI YAYINLAR}

\section{ÖZET}

Amaç- Bu çalışmanın amacı entelektüel sermaye üzerine çalışan akademisyenlerin son yıllarda en çok ilgilendikleri modellerden biri olan Pulic'in (1998; 2004) “entelektüel katma değer katsayısı (VAIC)” ile ilgili önemli akademik çalışmaları sınıflandırarak özellikle Türkçe literatüre katkı sağlamak ve gelecekteki araştırmacıların fikir sahibi olmasına katkıda bulunmaktır.

Yöntem- Literatür taramamızda, Web of Science veri tabanında bulunan, 2015-2020 yılları arasında yayınlanmış, konusunda "VAIC" ya da "value added intellectual capital" geçen ve araştırma alanı "Business", "Economics" ve "Business Finance" olarak belirtilmiş makalelere ilişkin genel özellikler, modeller ve değişkenler irdelenmiş ve sınıflanmıştır.

Bulgular- Bu literatür taraması çalışmasında analiz konusu çalışmaların \%65'den fazlasının 2018 ve sonrasında yayımlandığı tespit edildiğinden, son yıllarda akademik dünyada oldukça ilgi gören bir konu olduğunu ortaya koymaktadır. Literatür çalışmamız sonucunda, entelektüel sermayenin daha çok finansal performans üzerindeki etkisinin araştıııldığı ve bu etkiyi ölçmede ise genellikle panel veri regresyon yöntemi kullanıldığı sonucuna ulaşılmışıı. Analize dahil edilen 37 çalımanın tamamında VAIC ya da herhangi bir bileşenin ROA ile istatistiki olarak anlamlı ve pozitif ilişkilili olduğu tespit edilmişitir. Ancak, yalnızca 5 çalışmada VAIC ya da herhangi bir bileşenin ROA ile istatistiki olarak anlamlı ve negatif ilişikili olduğu tespit edilmiştir. Muhasebe ve finans literatürünü ele alan bu çalışmalarda; VAIC (Pulic, 1998; 2004) modifiye edilirken inovasyon harcamalarının, reklam harcamalarının ve sosyal refah harcamalarının dikkate alındığı tespit edilmiştir. 
Sonuç- Analiz bulgularına dayanarak son yıllarda entelektüel sermaye yatırımlarının şirketler için, sektör ayırt etmeksizin, giderek artan bir önem kazandığı sonucuna varılabilir. Elde edilen sonuçlara göre, VAIC ve bileşenlerinin ülke ya da sektör ayırt etmeksizin çalışmaların büyük çoğunluğunda finansal performansı artırdığı tespit edilmiştir. Ayrıca son yıllarda yapılan çalışmalar; "AR\&GE harcamaları" gibi inovasyon sermayesine yapılan ya da "reklam ve pazarlama harcamaları" gibi ilişkisel sermayeye yapılan yatırımların da entelektüel sermaye yatırımı olduğunu ve firmalara rekabet avantajı sağlayabildiklerini ortaya koymaktadır.

Keywords: Entelektüel sermaye, entelektüel katma değer katsayısı, finansal performans, inovasyon sermayesi, ilişkisel sermaye JEL Codes: O 34, E 22, L 25

\section{REFERENCES}

Al-Musali, M. A., \& Ismail, K. N. I. K. (2016). Cross-country comparison of intellectual capital performance and its impact on financial performance of commercial banks in GCC countries. International Journal of Islamic and Middle Eastern Finance and Management, 9(4), 512531.

Asare, N., Alhassan, A. L., Asamoah, M. E., \& Ntow-Gyamfi, M. (2017). Intellectual capital and profitability in an emerging insurance market. Journal of Economic and Administrative Sciences, 33(1), 2-19.

Bansal, D., \& Singh, S. (2020). Impact of intellectual capital on financial performance of the Indian software sector. Asia-Pacific Management Accounting Journal, 15(1), 67-95.

Bayraktaroglu, A. E., Calisir, F., \& Baskak, M. (2019). Intellectual capital and firm performance: an extended VAIC model. Journal of Intellectual Capital, 20(3), 406-425.

Bhatia, A., \& Aggarwal, K. (2015). Intellectual Capital and Financial Performance of Indian Software Industry: A Panel Data Analysis. Pacific Business Review International, 7(8), 33-43.

Chowdhury, L. A. M., Rana, T., Akter, M., \& Hoque, M. (2018). Impact of intellectual capital on financial performance: evidence from the Bangladeshi textile sector. Journal of Accounting \& Organizational Change, 14(4), 429-454.

Dženopoljac, V., Janoševic, S., \& Bontis, N. (2016). Intellectual capital and financial performance in the Serbian ICT industry. Journal of Intellectual Capital., 17(2), 373-396.

Dzenopoljac, V., Yaacoub, C., Elkanj, N., \& Bontis, N. (2017). Impact of intellectual capital on corporate performance: evidence from the Arab region. Journal of Intellectual Capital, 18(4), 884-903.

Ghosh, S. K., \& Maji, S. G. (2015). Empirical validity of value added intellectual coefficient model in Indian knowledge-based sector. Global Business Review, 16(6), 947-962.

Ginesti, G., Caldarelli, A., \& Zampella, A. (2018). Exploring the impact of intellectual capital on company reputation and performance. Journal of Intellectual Capital, 19(5), 915-934.

Gupta, K., Goel, S., \& Bhatia, P. (2020). Intellectual Capital and Profitability: Evidence from Indian Pharmaceutical Sector. Vision, 24(2), 204216.

Haris, M., Yao, H., Tariq, G., Javaid, H. M., \& Malik, A. (2018). The impact of intellectual capital and employee size on bank profitability: A comparative study of islamic and conventional banks in pakistan. Pacific Business Review International, 11, 66-82.

Haris, M., Yao, H., Tariq, G., Malik, A., \& Javaid, H. M. (2019). Intellectual capital performance and profitability of banks: Evidence from Pakistan. Journal of Risk and Financial Management, 12(2), 56.

Kasoga, P. S. (2020). Does investing in intellectual capital improve financial performance? Panel evidence from firms listed in Tanzania DSE. Cogent Economics \& Finance, 8(1), 1802815

Meles, A., Porzio, C., Sampagnaro, G., \& Verdoliva, V. (2016). The impact of the intellectual capital efficiency on commercial banks performance: Evidence from the US. Journal of Multinational Financial Management, 36, 64-74.

Mohammad, H. S., \& Bujang, I. (2019). Does intellectual capital influence firms' financial performance? A comparatıve analysıs into three Malaysıan industries. International Journal of Business \& Society, 20(1), 260-276.

Nadeem, M., De Silva, T. A., Gan, C., \& Zaman, R. (2017). Boardroom gender diversity and intellectual capital efficiency: evidence from China. Pacific Accounting Review, 29(4), 590-615.

Nadeem, M., Dumay, J., \& Massaro, M. (2019). If you can measure it, you can manage it: a case of intellectual capital. Australian Accounting Review, 29(2), 395-407.

Nawaz, T., \& Haniffa, R. (2017). Determinants of financial performance of Islamic banks: an intellectual capital perspective. Journal of Islamic Accounting and Business Research, 8(2), 130-142. 
Nazir, MI, Tan, Y, \& Nazir, MR. (2020). Intellectual capital performance in the financial sector: Evidence from China, Hong Kong, and Taiwan. Interntaional Journal of Finance Economics, 1-21.

Ousama, A. A., Hammami, H., \& Abdulkarim, M. (2020). The association between intellectual capital and financial performance in the Islamic banking industry. International Journal of Islamic and Middle Eastern Finance and Management, 13(1), 75-93.

Ozkan, N., Cakan, S., \& Kayacan, M. (2017). Intellectual capital and financial performance: A study of the Turkish Banking Sector. Borsa Istanbul Review, 17(3), 190-198.

Pulic, A. (1998). Measuring the Performance of Intellectual Potential in Knowledge Economy, 2nd World Congress of Measuring and Managing Intellectual Capital, Mc Master University, Hamilton.

Pulic, A. (2004), Intellectual capital - does it create of destroy value?, Measuring Business Excellence, 8(1), 62-68.

Singla, H. K. (2020). Does VAIC affect the profitability and value of real estate and infrastructure firms in India? A panel data investigation. Journal of Intellectual Capital, 21(3), 309-331.

Smriti, N., \& Das, N. (2018). The impact of intellectual capital on firm performance: a study of Indian firms listed in COSPI. Journal of Intellectual Capital, 19(5), 935-964.

Soetanto, T., \& Liem, P. F. (2019). Intellectual capital in indonesia: Dynamic panel approach. Journal of Asia Business Studies, $13(2), 240-262$.

Soewarno, N., \& Tjahjadi, B. (2020). Measures that matter: an empirical investigation of intellectual capital and financial performance of banking firms in Indonesia. Journal of Intellectual Capital, 21(6), 1085-1106.

Tandon, K., Purohit, H., \& Tandon, D. (2016). Measuring intellectual capital and its impact on financial performance: Empirical evidence from CNX Nifty Companies. Global Business Review, 17(4), 980-997.

Tiwari, R., \& Vidyarthi, H. (2018). Intellectual capital and corporate performance: a case of Indian banks. Journal of Accounting in Emerging Economies, 8(1), 84-105

Tran, D. B. \& Vo, D. H. (2018). Should bankers be concerned with Intellectual capital? A study of the Thai banking sector. Journal of Intellectual Capital, 19(5), 897-914.

Tran, N. P., \& Vo, D. H. (2020). Human capital efficiency and firm performance across sectors in an emerging market. Cogent Business \& Management, $7(1), 1738832$.

Weqar, F., Khan, A. M., Raushan, M., \& Haque, S. M. Measuring the Impact of Intellectual Capital on the Financial Performance of the Finance Sector of India. Journal of the Knowledge Economy, 1-18.

Xu, J., Haris, M., \& Yao, H. (2019). Should Listed Banks Be Concerned with Intellectual Capital in Emerging Asian Markets? A Comparison between China and Pakistan. Sustainability, 11(23), 6582.

Xu, X. L., \& Liu, C. K. (2019). How to keep renewable energy enterprises to reach economic sustainable performance: from the views of intellectual capital and life cycle. Energy, Sustainability and Society, 9(1), 7.

Xu, J., \& Liu, F. (2020). The Impact of Intellectual Capital on Firm Performance: A Modified and Extended VAIC Model. Journal of Competitiveness, 12(1), 161.

Xu, J., \& Wang, B. (2019a). Intellectual capital and financial performance of Chinese agricultural listed companies. Custos Agronegocio Line, 15, 273-290.

Xu, J., \& Wang, B. (2019b). Intellectual capital performance of the textile industry in emerging markets: A comparison with China and South Korea. Sustainability, 11(8), 2354.

Xu, X. L., Yang, X. N., Zhan, L., Liu, C. K., Zhou, N. D., \& Hu, M. (2017). Examining the relationship between intellectual capital and performance of listed environmental protection companies. Environmental Progress \& Sustainable Energy, 36(4), 1056-1066. 